\title{
Argentaffin and argyrophil reactions and serotonin content of endocrine tumours
}

\author{
CA WELLS, ${ }^{*}$ SM TAYLOR, ${ }^{*}$ AC CUELLO† \\ From the * Nuffield Department of Pathology, John Radcliffe Hospital, Headington, Oxford, and the \\ $\dagger$ Department of Pharmacology, University of Oxford, Oxford.
}

SUMMARY Sixty carcinoid tumours were tested in a retrospective study with an immunoperoxidase technique using a monoclonal antibody against serotonin immunoreactive sites, with argyrophil staining using the Grimelius technique, and with argentaffin staining using the Masson-Fontana technique. A good correlation between all three techniques in the diagnosis of ileal carcinoid tumour was found, but the immunoperoxidase technique showed greater sensitivity than the Masson-Fontana technique and greater specificity than the Grimelius technique in the diagnosis of foregut and hindgut carcinoid tumours. The immunoperoxidase technique with a monoclonal antibody against serotonin immunoreactive sites (YC5/45) is recommended as a sensitive and specific test for carcinoid tumours. The reactions in other endocrine tumours are also included.

The general histopathological diagnosis of carcinoid tumours is based on their morphology of an acinar or ribbon like pattern of regular cells with palisading around the edges of acini, set within fibrous stroma. The cells have eosinophilic cytoplasm on routine haematoxylin and eosin preparations. Occasionally, confirmation by special staining techniques including argentaffin and argyrophil stains is performed. Only in centres with a research interest is electron microscopy used to show dense core granules in these tumours.

The silver staining techniques of the argentaffin type which are currently used are time consuming and often show no reaction in foregut or hindgut carcinoid tumours.' ${ }^{1}$ Argyrophil stains, on the other hand, are much less specific for serotonin and stain many different neuroendocrine granules. While they may be useful in diagnosis, their importance in individual cases must be interpreted with caution. There is a current vogue for describing argyrophilia in many diverse tumours which have no known endocrine effects. These include some mucoid carcinomas of the breast, ${ }^{2}$ so called primary carcinoid tumour of the breast, ${ }^{34}$ lobular carcinoma in situ within fibroadenoma of the breast ${ }^{5}$ and occasionally focally within tumours otherwise characterised as adenocarcinomas $^{6}$ (see below).
Monoclonal antibodies may be produced in large quantities and this study attempts to assess their potential application to routine histopathological methods.

\section{Material and methods}

Routine formalin fixed, paraffin embedded blocks from the histopathological files of the John Radcliffe Hospital and Radcliffe Infirmary, Oxford, between the years 1945 and 1983 were sectioned at $2 \mu \mathrm{m}$ and stained by the indirect immunoperoxidase method. The primary antibody (coded YC5/45) ${ }^{78}$ (Seralab Ltd, Crawley Down, Sussex), which is the product of a rat $\times$ rat hybridoma, was applied for 30 min at room temperature at a dilution of $1 / 200$ (vol/vol) in 0.01 phosphate buffer containing $0.5 \mathrm{ml}$

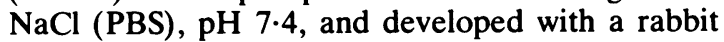
antirat IgG horseradish peroxidase conjugated antibody (Miles, UK), diluted $1 / 50$ ( $\mathrm{vol} / \mathrm{vol}$ ) in PBS. Occasional sections were subjected to colour modification by the cobalt metallic ion technique ${ }^{9}$ to produce a black reaction product against a green or light blue background, but this tended to produce poorer morphology of the granules. Normal human small intestine was used as a positive control for the immunoreaction. Negative controls were performed in the absence of primary antibodies, in other tumours and tissues generally believed not to contain serotonin storing cells (infiltrating ductal car- 
cinomas of breast, normal adrenal gland, normal human anterior pituitary gland), and in antigen excess using serotonin hydrochloride (Sigma). Sections were also stained by the Grimelius argyrophil silver staining technique ${ }^{10}$ and by the MassonFontana argentaffin technique. ${ }^{11}$

\section{ANTIBODIES}

The primary antibody (coded YC5/45) is the product of a rat $\times$ rat hybridoma. ${ }^{7}$ The antibody was raised against serotonin bovine serum albumin conjugate and tested and characterised by haemagglutination and immunocytochemistry. ${ }^{78}$ In fixed brain preparations immunoreactivity is seen on neurones known to contain serotonin while no reaction is seen in neurones containing catecholamines. The immunoreactivity is obliterated by the use of agents inhibiting the biosynthesis of serotonin (pchlorophenylalanine). Agents which deplete brain catecholamines ( $\alpha$-methyl-p-tyrosine) do not affect the reaction. ${ }^{78}$

\section{Results}

The positive controls showed the expected distribution of serotonin containing cells within crypts of intestinal mucosa, with neighbouring epithelial cells showing no immunoreactivity (Fig. 1). Occasional cells within the lamina propria but not connected to epithelial crypts also showed positivity (Fig. 1). Human adrenal and pituitary showed no reaction and neither did various breast tumours and neuroblastomas. Complete quenching of staining was achieved with the addition of serotonin hydrochloride in antigen excess to the primary antibody at the first stage.

The staining reactions of the carcinoid tumours tested are given in Table 1 . The staining pattern found in carcinoid tumours was a finely granular cytoplasmic reaction (Figs. 2 and 3). A variation in staining density was seen from tumour to tumour

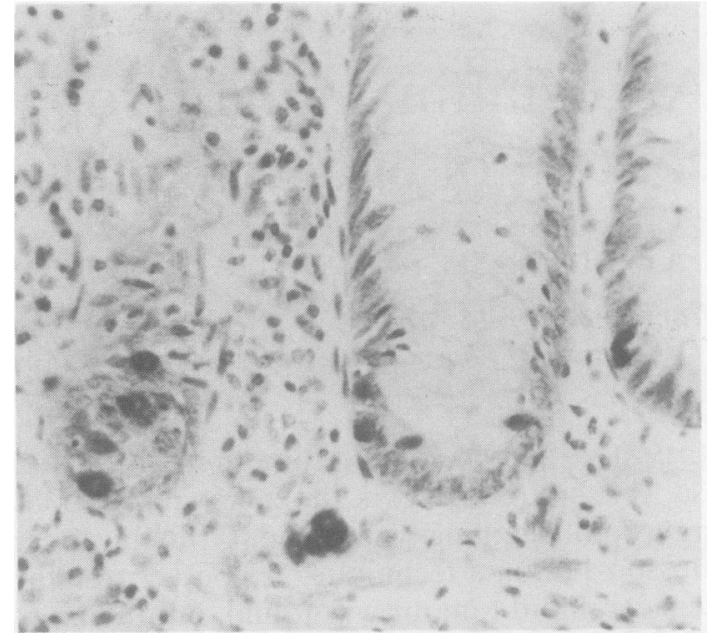

Fig. 1 Normal mucosa from base of appendix containing a carcinoid tumour at the tip. Note the normal positive cells in the crypts and the isolated group of positive cells in the lamina propria. Serotonin immunoperoxidase. $\times 320$

and within the same tumour. Condensation of the staining was seen around the periphery of tumour islands, and this was also seen with both argentaffin and argyrophil reactions.

Other tumours were also tested with the antibody, including one ovarian carcinoid tumour associated with bronchial epithelium in a benign cystic teratoma. These reactions are summarised in Table 2 . The seven colonic carcinomas tested included four which showed positivity on argyrophil staining, being selected for this reason. This argyrophilia was seen focally in occasional tumour areas while most of the tumour pattern was typical colonic adenocarcinoma with gland formation and central necrosis.

The serotonin staining within medullary carcinomas of the thyroid was focal in occasional cells scattered throughout the tumour (Fig. 4) and, in one case, in a small localised island of tumour cells.

Table 1 Staining reactions of carcinoid tumours

\begin{tabular}{|c|c|c|c|c|}
\hline Site & $\begin{array}{l}\text { No } \\
\text { of specimens }\end{array}$ & $\begin{array}{l}\text { Serotonin } \\
\text { immunoperoxidase } \\
\text { positive }\end{array}$ & $\begin{array}{l}\text { Argyrophil } \\
\text { positive }\end{array}$ & $\begin{array}{l}\text { Argentaffin } \\
\text { positive }\end{array}$ \\
\hline $\begin{array}{l}\text { Gastric } \\
\text { Duodenal } \\
\text { Ileum } \\
\text { Appendix } \\
\text { Meckel's diverticulum } \\
\text { Colon } \\
\text { Rectum } \\
\text { Bronchus } \\
\text { Ovarian } \\
\text { Liver metastases } \\
\text { Adenocarcinoid of appendix }\end{array}$ & $\begin{array}{r}2 \\
1 \\
22 \\
10 \\
1 \\
2 \\
2 \\
7 \\
1 \\
11 \\
3\end{array}$ & $\begin{array}{c}1^{*} \\
1^{*} \\
22 \\
10 \\
1 \\
2 \\
1^{*} \\
5^{*} \\
0 \\
10 \\
3^{*}\end{array}$ & $\begin{array}{r}2 \\
1 \\
22 \\
10 \\
0 \\
2 \\
1 \\
5 \\
1 \\
10 \\
3\end{array}$ & $\begin{array}{r}0 \\
0 \\
22 \\
10 \\
1 \\
1 \\
1 \\
1 \\
0 \\
9 \\
3\end{array}$ \\
\hline
\end{tabular}

*Indicates focal staining 


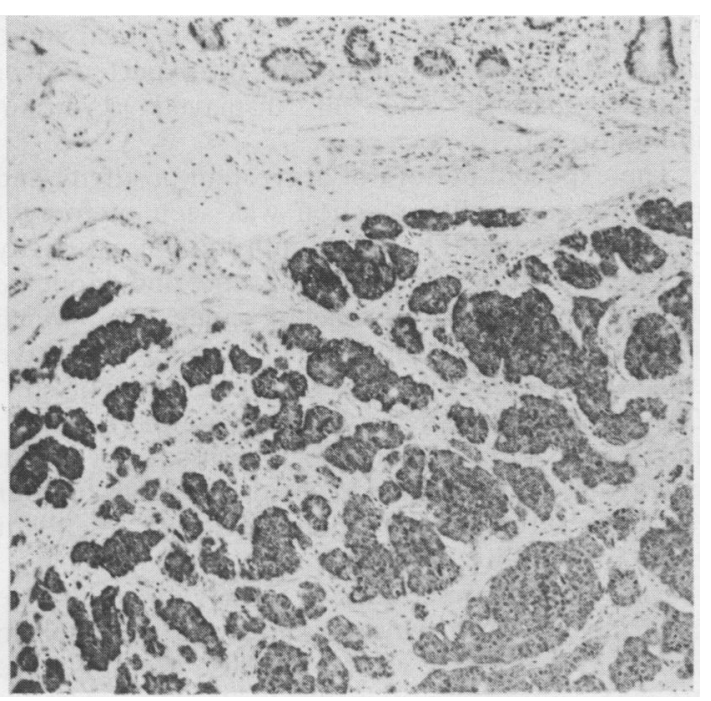

Fig. 2 Low power of ileal carcinoid tumour in ileal wall showing positive staining with condensation around the periphery of the cell islands. Serotonin immunoperoxidase. $\times 71$

The positive areas were not seen in every block tested and were in focal areas of the tumour only.

Of the five carotid paraganglionomas tested, four showed focal positivity in a similar manner to the medullary carcinomas of thyroid. The other paraganglionomas tested included those from the jugular region (one case), vagal (one case), and retroperitoneal (one case) (location unspecified) along with one laryngeal chemodactoma with multiple metastases, one paraganglioma of the filum terminale, and one paraganglionoma within the cervical spine. The two tumours positive with YC5/45 were the laryngeal tumour and the jugular paraganglioma, both of which showed focal staining as above.

Of the eight phaeochromocytomas stained two showed extremely weak reactions which were not considered important, while one showed focal

Table 2 Staining reactions of other related tumours

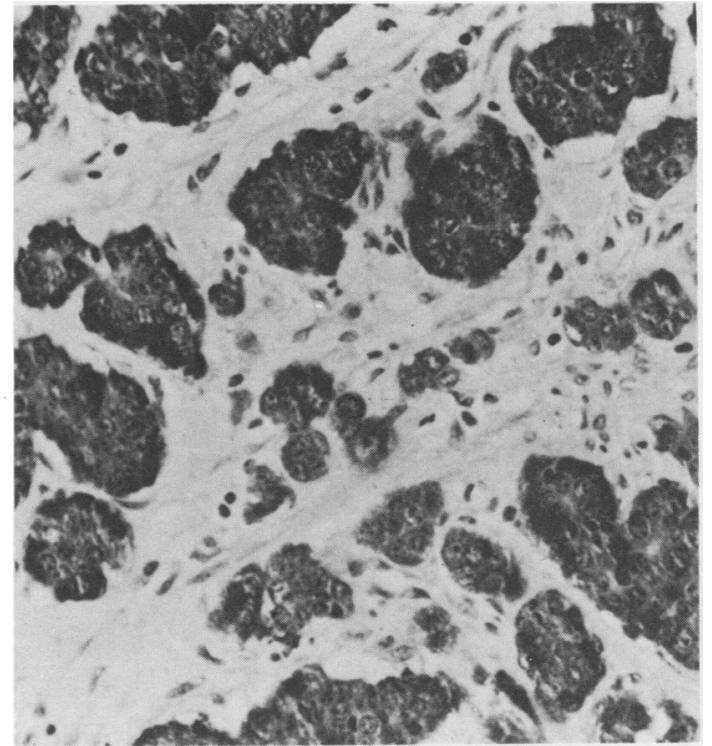

Fig. 3 Same tumour as in Fig. 2 at higher magnification showing the cytoplasmic reaction product. Serotonin immunoperoxidase. $\times 280$

positivity and was also argentaffin and argyrophil positive.

Of the seven bronchial tumours and the ovarian lesion which was associated with bronchial epithelium, only five stained with serotonin immunoperoxidase, and these five were only focally positive. Five also stained with the argyrophil technique, while only one stained with the argentaffin reaction. The case of metastatic carcinoid tumour within the liver which did not stain with the YC5/45 immunoperoxidase was also negative with Grimelius and Fontana techniques and was classified as a carcinoid tumour on haematoxylin and eosin morphology only. The primary tumour in this case was unknown.

Three neuroblastomas, two mucoid carcinomas of the breast, and five oat cell carcinomas of the lung

\begin{tabular}{|c|c|c|c|c|}
\hline Diagnosis & $\begin{array}{l}\text { No } \\
\text { of specimens }\end{array}$ & $\begin{array}{l}\text { Serotonin } \\
\text { immunoperoxidase } \\
\text { positive }\end{array}$ & $\begin{array}{l}\text { Argyrophil } \\
\text { positive }\end{array}$ & $\begin{array}{l}\text { Argentaffin } \\
\text { positive }\end{array}$ \\
\hline $\begin{array}{l}\text { "Carcinoid" variant of breast carcinoma } \\
\text { Colonic adenocarcinoma } \\
\text { Adenocarcinoma of ileum } \\
\text { Medullary carcinoma of thyroid } \\
\text { Carotid paraganglionomas } \\
\text { Other paraganglionomas } \\
\text { Islet cell adenomas } \\
\text { Islet cell carcinomas } \\
\text { Phaeochromocytoma }\end{array}$ & $\begin{array}{l}1 \\
7 \\
1 \\
5 \\
5 \\
7 \\
2 \\
4 \\
8\end{array}$ & $\begin{array}{l}0 \\
0 \\
0 \\
4^{*} \\
4^{*} \\
3^{*} \\
0 \\
2 \\
1\end{array}$ & $\begin{array}{l}1^{*} \\
4^{*} \\
0 \\
\text { NT } \\
\text { NT } \\
\text { NT } \\
1 \\
3 \\
1\end{array}$ & $\begin{array}{l}0 \\
0 \\
0 \\
\text { NT } \\
\text { NT } \\
\text { NT } \\
0 \\
2 \\
1\end{array}$ \\
\hline
\end{tabular}

*Indicates focal staining.

NT $=$ reaction not tested. 


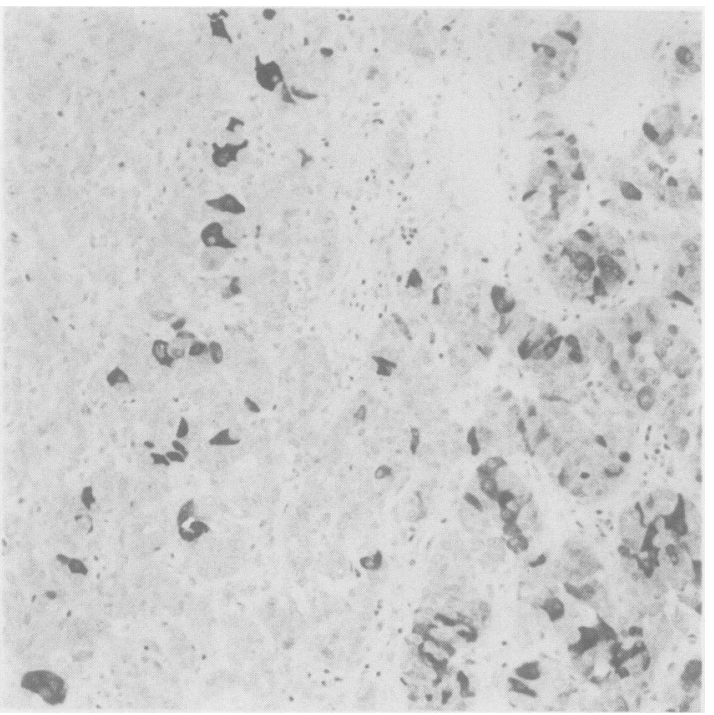

Fig. 4 Medullary carcinoma of the thyroid showing areas of heavily stained positive cells with a large area devoid of reaction. Serotonin immunoperoxidase. $\times 96$

showed no evidence of serotonin immunoreactivity. Other tumours tested and showing no evidence of immunoreactivity included one adenocarcinoma of the small intestine, two undifferentiated colonic tumours, one Merkel cell tumour of the skin, four infiltrating ductal and one infiltrating lobular carcinoma of the breast.

Occasional ganglion cells within a sympathetic chain removed at sympathectomy were positive on YC5/45 immunostaining. One colonic tumour diagnosed as endocrine on haematoxylin and eosin morphology was negative with all three stains.

\section{Discussion}

In the routine diagnosis of endocrine tumours the serotonin immunoperoxidase technique identifies certain cases which are negative by argentaffin techniques and excludes many of the reactions with argyrophil stains which may confuse the diagnosis, in particular the focal argyrophilia occasionally seen in otherwise unremarkable adenocarcinomas. ${ }^{412}$ It is of interest to note that occasional positive cells with the argyrophil techniques are considered by some authors ${ }^{13}$ to be of dubious importance and that a group of several cells should be seen in rectal tumours in order to label these as true carcinoid tumours.

The distinction of carcinoid tumours into foregut, midgut, and hindgut type ${ }^{114}$ is, in general, seen with the YC5/45 immunoperoxidase technique in that the ileal, appendiceal, and the one case of carcinoid of Meckel's diverticulum showed the expected silver staining pattern and all displayed serotonin immunoreactivity.

The expected pattern of argyrophil positivity and negative argentaffin reaction was seen in foregut carcinoid tumours, but serotonin immunoreactivity was present in two of the three gastric and duodenal lesions tested. The bronchial adenomas which showed serotonin positivity had occasional positive cells within them, similar to that recently reported. ${ }^{15}$ One, however, showed a midgut type of reactivity. In the case of foregut tumours occasional argentaffin positive cells may go undetected in a large tumour mass and serotonin immunoreactivity will highlight these much more readily.

Islet cell tumours show a variety of endocrine syndromes, one of which is similar to that seen in carcinoid tumours. ${ }^{16} 17$ Some of these tumours were YC5/45 immunoreactive (Table 2). One of these was associated with the carcinoid syndrome and adrenocorticotropic hormone production with adrenal hyperplasia. Adrenocorticotropic hormone immunostaining was also positive in this case. Argyrophil stains say little about the hormonal aspects of these tumours except to confirm their endocrine origin and further immunocytochemistry to define hormonal products is often performed.

Medullary carcinomas of the thyroid gland con- $\triangle$ tain calcitonin as their major hormonal product ${ }^{18} ; \overrightarrow{\vec{O}}$ however, not all dense core granules within normal $\mathrm{C}$ cells of pig thyroid contain immunoreactive calcitonin. ${ }^{19}$ Our observation that serotonin immunoreactivity is present in some of these tumours suggests that they also contain serotonin as ? a minor hormonal product. It has been previously suggested that prostaglandins, serotonin, adrenocorticotropic hormone, and calcitonin may be present within these heterogeneous granules. ${ }^{20-22}$ As expected, the amyloid component of the tumours did not contain serotonin.

Carotid body and other paragangliomas are generally thought to produce catecholamines, and $N$ reports do not indicate serotonin content by $N$ biochemical assay ${ }^{23}$ or by argentaffin stains, ${ }^{24} \mathrm{~N}$ although one case tested with polyclonal antiseroto- $\omega$

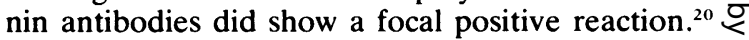
We believe that the failure to detect serotonin in 0 these tumours by non-immunocytochemical $\mathbb{D}$ methods is a problem of sensitivity and that some? contain small amounts of immunoreactive serotonin besides large amounts of catecholamines (Table 2). The negative staining found in all but one of the intra-adrenal phaeochromocytomas and the initial $\stackrel{\mathbb{Q}}{\varrho}$ characterisation and quenching would indicate that $\overline{2}$ the antibody is not cross reacting with

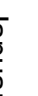


catecholamine precursors. The one phaeochromocytoma which did stain also showed a positive argentaffin reaction.

It is becoming increasingly apparent that many endocrine tumours may show evidence of production of more than one hormone by certain clones within the tumour and true carcinoid tumours certainly show other hormonal products besides serotonin. ${ }^{2526}$ Tumours of the diffuse neuroendocrine system may produce hormones not apparently appropriate to the tissue in which they arise. One interpretation of this is that of ectopic hormone production. The other suggestion is that these cells, besides having a capacity for the handling of biogenic amines, also produce a wide range of polypeptide hormones which should be regarded as being appropriate to cells of this diffusely organised system.

Another practical aspect of this study is the demonstration that stored material is amenable to retrospective research. The antigen under investigation showed remarkable stability in routine paraffin blocks, the earliest cases tested being from the files of 39 years ago.

This study follows on from a preliminary communication $^{27}$ and extends this to include other endocrine tumours. The use of YC5/45 to show serotonin immunoreactive sites resulted in greater specificity for demonstrating these sites than the argyrophil reaction and showed enhanced sensitivity over the commonly used argentaffin techniques. We therefore conclude that serotonin immunoreactivity with monoclonal antibodies provides a simpler, more reliable procedure for the diagnosis of carcinoid tumours than the commonly used argentaffin stains. Serotonin immunoreactivity may also be of value in determining hormone products within medullary carcinomas, paragangliomas at various sites, and in islet cell tumours. Argyrophil reactions are still recommended in the diagnosis of bronchial, rectal, and colonic neoplasms if serotonin is not found, although the results should be interpreted in conjuction with the haematoxylin and eosin morphology.

CW wishes to thank Dr D Tarin and Professor J O'D McGee for advice; Dr C Milstein for materials and helpful critical comments; and Miss TJ Chisnall for typing this manuscript.

ACC acknowledges grants from the Medical Research Council and the Wellcome Trust for the production of antibodies.

\section{References}

' Marks C. Carcinoid tumours - A clinicopathologic study. Boston, Massachusetts: GK Hall and Co, 1979.

${ }^{2}$ Capella C, Eusebi V, Mann B, Azzopardi JG. Endocrine differentiation in mucoid carcinoma. Histopathology 1980; 4:613-30.
${ }^{3}$ Taxy JB, Tischler AS, Insalaco SJ, Battifora H. "Carcinoid" Tumour of the Breast. Hum Pathol 1981;12:170-9.

${ }^{4}$ Fetissaf F, Dubois M, Arbeille-Brassart B, Lansac J, Jobard P. Argyrophilic cells in mammary carcinoma. Hum Pathol $1983 ; 14: 127-34$.

${ }^{5}$ Eusebi V, Azzopardi JG. Lobular endocrine neoplasia in fibroadenomas of the breast. Histopathology 1980;4:413-28.

- Kubo T, Watanabe H. Neoplastic argentaffin cells in gastric and intestinal carcinomas. Cancer 1971;27:447-54.

${ }^{7}$ Consolazione A, Milstein C, Wright B, Cuello AC. Immunocytochemical detection of serotonin with monoclonal antibodies. J Histochem Cytochem 1981;29:1425-30.

${ }^{8}$ Milstein C, Wright B, Cuello AC. The discrepancy between the cross-reactivity of a monoclonal antibody to serotonin and its immunocytochemical specificity. Mol Immunol 1983;20: 113-23.

${ }^{9}$ Hsu S-M, Soban E. Color modification of diaminobenzidine (DAB) precipitation by metallic ions and its application for double immunohistochemistry. $J$ Histochem Cytochem 1982;30: 1079-82.

${ }^{10}$ Grimelius L. A silver nitrate stain for $\alpha_{2}$ cells in human pancreatic islets. Acta Soc Med Upsal 1968;73:243-70.

"Singh I. A modification of the Masson-Hamperl method for staining of argentafin cells. Anatomischer Anzeige 1964;113:81-2.

12 Clayton F, Ordonez N, Sibley R, Hanssen G. Argyrophilic breast carcinomas. Evidence of lactational differentiation. Am J Surg Pathol 1982; 6:323-33.

${ }^{13}$ Taxy JB, Mendelsohn G, Gupta PK. Carcinoid tumours of the rectum. Am J Clin Pathol 1980;74:791-5.

${ }^{14}$ Godwin JD. Carcinoid tumours an analysis of 2837 cases. Cancer 1975;36: 561-9.

is Bosman FT, Brutel De La Riviere A, Giard RWM, Verhofstad AAJ, Cramer-Knijnenburg G. Amine and peptide hormone production by lung carcinoid: a clinicopathological and immunocytochemical study. J Clin Pathol 1984;37:931-36.

${ }^{16}$ Larsson L, Grimelius L, Hakanson R, et al. Mixed endocrine pancreatic tumours producing several peptide hormones. Am J Pathol 1975; 79:271-84.

${ }^{17}$ Schein P. NIH Conference. Islet cell tumours: current concepts and management. Ann Int Med 1973;79:239-57.

${ }^{18}$ Huang S-N, Goltzman D. Electron and immunoelectron microscopic study of thyroidal medullary carcinoma. Cancer 1978;41:2226-35.

${ }^{14}$ De Grandi PB, Kraehenbuhl JP, Campiche MA. Ultrastructural localisation of calcitonin in the para-follicular cells of the pig thyroid gland with cytochrome c-labeled antibody fragments. J Cell Biol 1971;50:448-56.

${ }^{20}$ Sherman SP, Chin Yang L, Carney JA. Microproliferation of Enterochromaffin cells and the origin of carcinoid tumours of the ileum. Arch Pathol Lab Med 1979; 103:639-41.

2 Deftos LJ. Calcitonin in clinical medicine. Adv Int Med 1978; 23: 159-94.

${ }^{22}$ Moertel CG, Beahrs OH, Woolner LB, Tyce GM. "Malignant carcinoid syndrome" associated with non-carcinoid tumours. $N$ Engl J Med 1965; 273:244-8.

${ }^{23}$ Grimley PM, Glenner GG. Histology and ultrastructure of carotid body paragangliomas. Cancer 1967; 20:1473-87.

${ }^{24}$ Robertson DI, Cooney TP. Malignant carotid body paraganlioma. Cancer 1980;46:2623-33.

${ }^{25}$ Ratzenhofer M, Gamse R, Hofler H, Aubock L, Popper H, Pohl $P$, Lembeck F. Substance $P$ in an argentaffin carcinoid of the caecum. Virch Arch [Pathol Anat] 1981;392:21-31.

${ }^{26}$ Yang K, Ulich T, Cheng L, Lewin J. The neuroendocrine products of intestinal carcinoids. Cancer 1983;51:1918-26.

${ }^{27}$ Cuello AC, Wells CA, Chaplin AJ, Milstein C. Serotonin immunoreactivity in carcinoid tumours demonstrated by a monoclonal antibody. Lancet 1982;i:771-3.

Requests for reprints to: Dr CA Wells, Nuffield Department of Pathology, John Radcliffe Hospital, Headington, Oxford OX3 9DU, England. 